\title{
Factors associated with drug use among adolescents
}

\author{
Mirene Peloso ${ }^{(1)}$, Brunnella Alcantara Chagas de Freitas ${ }^{\circledR}$, \\ Bruno David Henriques' ${ }^{(\mathbb{D})}$, Samuel de Souza Magalhães Marques'(i), \\ Luciana Moreira Lima'(i)
}

'Universidade Federal de Viçosa, Viçosa, MG, Brasil

\begin{abstract}
The study aimed to identify factors associated to drug use in adolescents. For this purpose, it has been observed 133 adolescents registred in ninth grade in two municipal schools in Viçosa, who answered an individual questionnaire validated by $\mathrm{PAHO} / \mathrm{WHO}$, applied by members of the Uncensored Extension Project of the Federal University of Viçosa (UFV). Substance use and family structure were evaluated. Statistical tools were: Epi-Info 7.0 StatCalc, Pearson's chi-square test, Poisson regression and SPSS version 23.0 and Stata 9.0 programs. The sample had an average of 15 years old, that $26.3 \%$ reported drug use, thus, $65,4 \%$ related family history of drug use and low education. Other aspects of family structure included: good family perception, absence of violence and family mental disorder by $78.2 \%, 82.7 \%$ and $75.9 \%$ of adolescents, respectively. Only males persisted as a factor associated with drug use, with 2.4 times higher use (PR 2.39; 95\% IC 1.19-4.78; $p=0.014$ ). Therefore, only the male gender showed a higher risk for drug use, and further studies are needed to evaluate factors associated with drug use, aiming to promote public health.
\end{abstract}

Keywords: Adolescents; Substance Use Disorder; Mental Health

\section{INTRODUCTION}

The period of adolescence is a crucial moment in the life of the person, being a defining phase of physical and psychosocial characteristics that last for the rest of the life. It involves a process of physical and emotional transformations, as well as the search for personal identity, social acceptance and new experiences. Questions, curiosities, desire for autonomy arise. 
One of the consequences of these aspects is the use of licit and illicit drugs, like alcohol, tobacco, marijuana, cocaine, ecstasy, perfume launches and others (SKOGEN et al., 2018). In Brazil, there has been an important change in this scenario in the last years. Before the 1980s, student's consumption rates weren't epidemiologically significant (MORGADO; IGUCHI; BUENO, 1983). In 1987, according to the Brazilian Center for Information on Psychotropic Drugs at the Federal University of São Paulo (CEBRID), data had showed an increase in consumption, a fact that also occurred in 1997 (MARQUES; CRUZ, 2000). According to the National Health Survey (PeNSE), 8,7\% of adolescents living in the state capitals had experienced illicit drugs in 2009 (BRASIL, 2009). In 2012 this percentage increased to 9.9\%, which is more than 312 thousand adolescents (BRASIL, 2012).

Ignorance of substance use damage, the influence of external factors and the dependence on each drug can make adolescents become drug addicted, what increases the risk of acquiring a series of cardiovascular, hepatic, oncological and psychiatric diseases (SIEGFRIED et al., 2013). This situation encumbers the public health system and generates harmful consequences, such as learning disabilities, risk of car accidents, early sex initiation, unprotected sex, and others (SANTOS MODELLI; PRATESI; TAUIL, 2008)(STOCKWELL et al., 2000) (REIS, 2020).

During adolescence the young person consolidates his personality and establishes habits that will be taken to adulthood, therefore, it is necessary to define possible risk factors and protection against drug use, since inappropriate behaviors and addictions in this phase can be perpetuate and bring life-long consequences (SCHENKER; MINAYO, 2005). The social and family context is essential and can positively or negatively influence adolescents (SKOGEN et al., 2018) (SCHENKER; MINAYO, 2003). Other factors, such as misinformation and sense of judicial impunity, make teenagers look for ways that easily promote pleasure or make them escape their reality, being narcotics a strong ally. It's necessary to remember the homeless young people, who are often at a higher risk of drug addiction, as a way to suppress their appetite, be accepted and escape reality (RIZZINI; COUTO, 2019), hereby $d$ this question should also be treated with attention by public authorities.

The aim of the present study was to identify factors associated with licit and illicit drug use in ninth grade adolescents in a Brazilian city, considering the family context in which the individual is inserted. 


\section{MATERIAL AND METHODS}

\subsection{Study characterization}

This is a cross-sectional study conducted with 133 adolescents regularly enrolled in the ninth grade of two elementary schools, the Coronel Antonio da Silva Bernardes Municipal School (CASB) and the Padre Francisco José da Silva Municipal School, both located in the urban area of Viçosa, Minas Gerais, Brazil, from February 2015 to December 2016.

\subsection{Population and study place}

Viçosa is a city in the state of Minas Gerais, Brazil, with an estimated population of 77,863 inhabitants, according to IBGE estimates in 2016. It has 40 schools and, of these, 21 have the ninth grade of primary education, distributed as follows: eight state, seven municipal and six private. The total number of students in ninth grade in public schools in the municipality was 616 adolescents, data related to the year 2016.

Two municipal schools were selected. The first, CASB, was chosen since it is located in the center of the city, accepts students from all neighborhoods and has a large number of students, 59 participants in ninth grade in 2016 and 50 in 2015, out of a total of 1300 students enrolled in ninth grade in those two years. The second, Padre Francisco José da Silva Municipal School, was selected because it represents an institution on the outskirts of the city and for notoriously presenting higher socioeconomic risk factors such as drug use and violence. From this school, 24 students from the ninth year of 2016 participated in this study and it is not possible to account for the total number of students in this period.

\subsection{Study variables}

Data collection was performed during the school year using an individual questionnaire validated by PAHO / WHO (BRASIL, 2007). Starting it, the principals of the schools were contacted, who authorized this study. The adolescents were previously informed about the content of the questionnaire and the project 
objectives, being assured of confidentiality, aiming at greater candor in their answers, besides being offered the opportunity to choose whether or not to participate in the study.

The parents or guardians of the participants signed the Informed Consent Form (ICF) and the adolescents signed the consent form, agreeing to participate in the study. At the time of the interview, the students were removed from the classroom and taken to a reserved area at the school, where the questionnaire was applied individually and privately by a student of Medicine or Nursing at the Federal University of Viçosa (UFV), participant in the "Project Without Censorship". This is an extension project created in 2015 by students and teachers of the Department of Medicine and Nursing, which aims to draw the epidemiological profile of 9th grade students from municipal schools in Viçosa/MG, in order to hold awareness workshops on relevant topics according to the needs presented by the population.

The questionnaire was based on the PAHO / WHO Adolescent History and assessed sociodemographic characteristics, medical and social history, both personal and family, variables for analysis of family structure, sexuality, psychoemotional situation, social life and habits, which included licit and illicit drug use.

Regarding drug use, the following variables were evaluated: (a) alcohol use and quantity (equivalent to liters of beer or distilled per week); (b) tobacco use and quantity (in number of cigarettes per day) and age of smoking initiation; (c) the use of other toxic substances, the frequency and the type of drug used. If the teenager answered yes to some of these items, he or she would be considered a drug user.

Aiming the analysis of family structure, the questionnaire included questions regarding the following variables: (a) history of mental disorders, both personal and family, which may be eating, cognitive, personality, adjustment, mood, development, sleep, sexual or even caused by substances; (b) history of maltreatment; (c) intrafamily violence; (d) legal, personal and family problems, whether involving marital separation or divorce from parents, investigation of the paternity of the user or family members, accusations of committing a crime, like theft or murder, application of child support, violation of environment and involvement in accident; (e) teenager mother, that is, those who became pregnant 
under the 20 years old; (f) alcohol or drug use in the family; (g) parental level of education, being considered low education when the parents had only complete elementary school, incomplete or no schooling and (h) family perception of the adolescent.

\subsection{Statistical analysis}

The sample size was calculated by the Epi-Info 7.0 StatCalc and, considering the prevalence of alcohol consumption $27.3 \%$, adding to $80 \%$ study power and $95 \%$ significance, would require 130 adolescents (BRASIL, 2007). For the descriptive analysis, qualitative variables were described as absolute and percentage values.

"Drug use" was defined as outcome variable. The other variables were analyzed as explanatory. To test comparisons between categorical variables, the analyzes were performed by Pearson's chi-square test. Prevalence ratios (PR) were obtained by Poisson regression. In the regression analyzes, the explanatory variables that presented $p<0.20$ to the bivariate analysis were included. The final model included significant variables at the 0.05 level. For the analyzes we used the statistical programs SPSS version 23.0 and Stata 9.0.

\subsection{Ethical aspects}

The study was approved by the UFV Research Ethics Committee (CEP) under opinion CAAE 42236815.4.0000.5153 and is an integral part of the Master of Science dissertation of the Department of Medicine and Nursing of the UFV.

\section{RESULTS AND DISCUSSION}

Data were obtained from 134 adolescents enrolled in the ninth grade of elementary school from the previously mentioned schools. However, one student chose don't participate in the questionnaires and the study population was 133 students. Participants' ages ranged from 13 to 18 years, with an average of 15 years. The sociodemographic characteristics of the interviewed adolescents are shown in table 1. 
Table 1 - Characteristics of the study population - adolescents in the ninth grade of elementary school, Viçosa-MG, 2015-2016 ( $n$ = 133)

\begin{tabular}{lc}
\hline \multicolumn{1}{c}{ Variable } & $\mathbf{n}(\%)$ \\
\hline Gender & $55(41,4)$ \\
Male & $78(58,6)$ \\
Female & $35(26,3)$ \\
\hline Drug use & $98(73,7)$ \\
Yes & \\
No & $16(12,0)$ \\
\hline Mistreatment & $117(88,0)$ \\
Yes & \\
No & $87(65,4)$ \\
\hline Drugs in Family & $46(34,6)$ \\
Yes & \\
No & $23(17,3)$ \\
\hline Family violence & $110(82,7)$ \\
Yes & \\
No & $40(30,1)$ \\
\hline Teenage mother son & $93(69,9)$ \\
Yes & \\
No & $23(17,3)$ \\
\hline Family judicial problems & $110(82,7)$ \\
Yes & \\
No & $32(24,1)$ \\
\hline Family psychiatric disorders & $101(75,9)$ \\
Yes & \\
No & $87(65,4)$ \\
\hline Low parental education & $46(34,6)$ \\
Yes & $104(78,2)$ \\
No & $29(21,8)$ \\
Yes &
\end{tabular}

Source: Authors (2020)

As shown in table $1,58.6 \%$ of the adolescents participating in the study were female. Respectively: $88 \%, 82.7 \%, 75.9 \%$ and $78.2 \%$ of adolescents denied abuse, family violence, family psychiatric disorders and good family perception. It was found that $69.9 \%$ were not children of teenage mothers and $82.7 \%$ had no family problems.

On the other hand, there are high prevalence of drug abuse by family members (65.4\%) and low levels of education of parents or guardians (65.4\%) were found. Regarding both licit and illicit drug use, about a quarter of the participants $(26.3 \%, \mathrm{n}=35)$ responded positively. 
According to the data in tables 2 and 3, the variables gender, family drug use, family violence, children of teenage mothers, and family judicial problems were $p$ $<0.20$ for the outcome drug use and were included in the multivariate analysis by the Poisson regression method. In the final model, represented by Table 3, only male gender persisted as a factor associated with drug use, that is, the prevalence of drug use was 2.4 times higher among male adolescents when compared to female (PR 2.39; 95\% Cl 1.19-4.78; $\mathrm{P}=0.014$ ).

Table 2 - Characteristics of the study population according to drug use - ninth grade adolescents, Viçosa/MG, 2015-2016 ( $n=133)$

\begin{tabular}{|c|c|c|c|}
\hline \multirow{3}{*}{ Variables } & \multicolumn{2}{|c|}{ Drug Use } & \multirow{3}{*}{$p^{*}$} \\
\hline & Yes & No & \\
\hline & n (\%) & n (\%) & \\
\hline Gender & & & 0,003 \\
\hline Male & $22(62,9)$ & $33(33,7)$ & \\
\hline Female & $13(37,1)$ & $65(66,3)$ & \\
\hline Mistreatment & & & 0,633 \\
\hline Yes & $5(14,3)$ & $11(11,2)$ & \\
\hline No & $30(85,7)$ & $87(88,8)$ & \\
\hline Drugs in family & & & 0,011 \\
\hline Yes & $29(82,9)$ & $58(59,2)$ & \\
\hline No & $6(17,1)$ & $40(40,8)$ & \\
\hline Family violence & & & 0,010 \\
\hline Yes & $11(31,4)$ & $12(12,2)$ & \\
\hline No & $24(68,6)$ & $86(87,8)$ & \\
\hline Teenage mother son & & & 0,055 \\
\hline Yes & $15(42,9)$ & $25(25.5)$ & \\
\hline No & $20(57,1)$ & $73(74,5)$ & \\
\hline Family judicial problems & & & 0,002 \\
\hline Yes & $12(34,3)$ & $11(11,2)$ & \\
\hline No & $23(65,7)$ & $87(88,8)$ & \\
\hline Family psychiatric disorders & & & 0,513 \\
\hline Yes & $7(20,0)$ & $25(25,5)$ & \\
\hline
\end{tabular}




\begin{tabular}{|c|c|c|c|}
\hline No & $28(80,0)$ & $73(74,5)$ & \\
\hline & & & Continuation... \\
\hline \multicolumn{4}{|l|}{ Conclusion } \\
\hline \multirow{3}{*}{ Variables } & \multicolumn{2}{|c|}{ Drug Use } & \multirow{3}{*}{ p* } \\
\hline & Yes & No & \\
\hline & n (\%) & n (\%) & \\
\hline Low parental education & & & 0,965 \\
\hline Yes & $23(65,7)$ & $64(65,3)$ & \\
\hline No & $12(34,3)$ & $34(34,7)$ & \\
\hline Good family perception & & & 0,259 \\
\hline Yes & $25(71,4)$ & $79(80,6)$ & \\
\hline No & $10(28,6)$ & $19(19,4)$ & \\
\hline
\end{tabular}

Source: Authors (2020)

In were: * p-value by Pearson's chi-square test

Table 2 - Bivariate and multivariate analyzes among the variables included in the model for the outcome drug use among ninth grade adolescents, Viçosa/MG, 2015-2016 ( $n=$ 133)

\begin{tabular}{|c|c|c|c|c|}
\hline Variáveis & Gross RP (Cl 95\%) & p-value* & Adjusted RP (CI 95\%) & p-value * \\
\hline Gender & & 0,012 & & 0,014 \\
\hline Male & $2,40(1,21-4,76)$ & & $2,39(1,19-4,78)$ & \\
\hline Female & 1,00 & & & \\
\hline Drugs in family & & 0,036 & & \\
\hline Yes & $2,56(1,06-6,16)$ & & - & - \\
\hline No & 1,00 & & & \\
\hline Family violence & & 0,031 & & \\
\hline Sim & $2,19(1,07-4,47)$ & & - & - \\
\hline Não & 1,00 & & & \\
\hline Teenager mother son & & 0,104 & & \\
\hline Yes & $1,74(0,89-3,41)$ & & - & - \\
\hline No & 1,00 & & & \\
\hline Family judicial problems & & 0,010 & & \\
\hline Yes & $2,49(1,24-5,01)$ & & - & - \\
\hline No & 1,00 & & & \\
\hline
\end{tabular}

Source: Authors (2020)

In were: RP: prevalence ration; $\mathrm{Cl}$ : 95\%: confidence interval; *Poisson regression

\section{DISCUSSION}


The present study found that of all characteristics observed and related to drug use in adolescents, only the male gender was statistically significant, data corroborated by the current literature. At the end of the study it was found that a quarter of participants $(26.3 \%, n=35)$ responded positively to the use of drugs, whether licit such as tobacco and alcohol, or illicit, like marijuana and perfume launcher. Current or past use has been considered. According to the National School Health Survey (PeNSE), conducted in 2015, this percentage is lower than expected for ninth grade adolescents, 50\% (MALTA et al., 2011).

Recent studies indicate that the current Brazilian scenario regarding drug use is worrying. In a study carried out in Rio Grande do Sul with high school students, in 2013 , it was found that $99.1 \%$ of adolescents had used some type of drug during their lifetime (BRASIL, 2015). The VI National Survey on Drug Use 2010, conducted with 50,000 elementary and high school students, indicates that $60.5 \%$ used alcohol, 16.9\% used tobacco and $25.5 \%$ used other drugs during their lifetime (MIOZZO et al., 2013). These statistics are alarming, taking into account the relationship between drug use in adolescence and damage to the central nervous system at the molecular level and also with behavioral risk that would result in early death, even on legal drugs (SALMANZADEH et al., 2020).

One of the limitations, as it is a cross-sectional study, is the absence of longitudinal follow-up of the analyzed population. Another factor that may have influenced the outcome includes the way the questionnaire was applied: verbal argumentation, direct and concise questions, which made it impossible to response variations. Besides that, the questionnaire was applied by interviewers, drug use is considered a taboo in our society. Therefore, a embarrassment may have existed and influenced the outcome. So, one way to reduce this embarrassment and better identify the target audience would be to apply written and anonymous questionnaires.

The analysis of the obtained data raises some suspicions about what makes young people to consume alcohol, tobacco and illicit drugs. Nevertheless, because 
of the characteristics of the cross-sectional study, it isn't possible to consider them as risk factors. Taking this precept as a basis, it can be quantitatively observed that the drug use in the population of adolescents of school age was higher in males, as well as in those with reported family violence, drug use by family members, those who had a family member with judicial problems, son of teenage mothers, and those with low-educated parents.

Among these variables, the only one that was significant was the male gender, presenting about 2.4 times greater chance of taking drugs than students of the opposite gender and this result are compatible with previous analyzes. A study conducted in Porto Velho, Rondônia, Brazil found that alcohol abuse is higher in male students and that tobacco and drug abuse is higher in alcoholic adolescents (CARLINI et al., 2010). Another study conducted in Recife, Pernambuco, Brazil, found the same predominance of drug use in men, youth and adults (ELICKER et al., 2015). PeNSE, in 2015, found that the use of tobacco and illicit drugs was higher in boys, but alcohol was higher in girls (MALTA et al., 2011). This may have family implications, such as raising children more liberally in many aspects, such as drug and sexual issues. Moreover, there are cultural, social and individual aspects, given that drug use is historically more accepted in men, such as for inclusion in a certain cycle of friendships, in addition to the fact that male individuals are more often exposed risk situations, such as accidents, homicides, substance use, among others (ALMEIDA, 2017) (NASCIMENTO; TRINDADE, 2010).

Before these results, it's evident the necessity to adopt strategies in the city to approach and prevent drug use by adolescents, especially males, based on the National Policy for Attention to the User of Alcohol and other Drugs. It is necessary to create living spaces aiming the reception of these students, discussion and exchange of experiences, with insertion of specific demands of the male gender. A multidisciplinary approach is fundamental toward the success of this coping strategy, as well as reinforce the training and qualification of the professionals working in the Health at School Program (PSE), instituted in 2007 in order to expand 
specific health actions to the public-school students. It is worth mentioning that potential interventions in this population should be carefully considered, ensuring adequate reception in order to increase their adherence to possible strategies that were implemented (SOUZA, 2005).

Although the other data do not have statistical significance for the study, they should also be considered important factors in the context analysis involving drug use by adolescents. Therefore, the family structure stands out as one of the pillars of understanding the motivation for the consumption of these substances. Then, risk factors for the onset and continuity of drug use among adolescents include violence and drug use in families, difficulty raising children, indiscipline, and drug use by siblings (GONCALVES, et al 2019). However, the present study was unable to corroborate these findings in the literature. Despite the fact that the family context did not remain significant after the final analyzes of our study, it is well-known that it constitutes an important mediator of the adolescent's chances of greater or lower risk of drug use and should be emphasized, since family acts as a support and example model for the teenager. It's in charge of instituting the individual's primary relationships with the environment since childhood and ends up dictating the way the teenager reacts and behaves on the subject of "drug use". Thus, a good family perception, the absence of stressors and family conflicts can serve as protective factors, and so a strengthened bond and a healthy relationship with the family will disadvantage the search for drugs as a solution to problems. With this, the family should also be approached in interventions with adolescents (BARRETO, 2000).

As strengths of this study, we highlight its relevance to the schools involved in the research. The sample analyzed allows a better knowledge of the local reality in order to support the formulation of strategies to approach and prevent drug use by adolescents, with a greater emphasis on males. It is important to highlight that individual medical care was made available to the adolescents who wanted it, at the adolescent medical ambulatory of the UFV. As weaknesses, sampling does not 
allow extrapolation of statistical analyzes and the cross-sectional feature does not allow risk analysis, but rather associations. This study is a pioneer in the municipality and at a later stage, will be expanded to other public schools. data on drug use will be expanded and detailed. We suggest further studies in this area in order to obtain data that can be extrapolated and provide substrate to support the proposed interventions, helping to promote health and prevent immediate and future complications related to licit and illicit drug use

\section{CONCLUSION}

Considering that drug use among adolescents is a public health problem, in this study we could verify that, among all the characteristics related and observed to drug use, male adolescents presented a 2.4 times greater chance of consumption compared with the female. Thus, from this study, it becomes evident the need to expand and detail the analysis of associated factors in order to foster the planning and execution of current programs. Addressing drug use among adolescents requires specific interventions by health and education professionals and authorities involved with teenagers.

\section{ACKNOWLEDGEMENT}

National Council for Scientific and Technological Development (CNPq) and University Extension Program / Ministry of Education and Culture (PROEXT / MEC).

\section{REFERENCES}

ALMEIDA, N. D. Uso de álcool, tabaco e drogas por jovens e adultos da cidade de Recife. Psicologia Argumento, 2017. doi: 10.7213/rpa.v29i66.20285.

BARRETO, Lelio Muniz; Dependência Química nas escolas e nos locais de trabalho. Rio de Janeiro: Qualitymark, 2000. 
BRASIL; A Saúde de Adolescentes e Jovens: Uma metodologia de auto-aprendizagem para equipes de atenção básica de saúde módulo básico. 2. ed. Brasília: MS, 2007.

BRASIL. Ministério da Saúde. Pesquisa Nacional de Saúde do Escolar 2009. Disponível em : https://biblioteca.ibge.gov.br/visualizacao/livros/liv43063.pdf. Acesso em: 23 jan. 2020.

BRASIL. Ministério da Saúde. Pesquisa Nacional de Saúde do Escolar 2012. Disponível em: https://servicodados.ibge.gov.br/Download/Download.ashx?http=1\&u=biblioteca.ibge.gov.br/ visualizacao/livros/liv64436.pdf. Acesso em: 23 jan. 2020.

BRASIL. Ministério da Saúde. Pesquisa Nacional de Saúde do Escolar 2015. Disponível em: https://biblioteca.ibge.gov.br/visualizacao/livros/liv97870.pdf. Acesso em: 23 jan. 2020.

CARLINI, E. L. DE A. et al. VI Levantamento Nacional sobre o Consumo de Drogas Psicotrópicas entre Estudantes do Ensino Fundamental e Médio das Redes Pública e Privada de Ensino nas 27 Capitais Brasileiras 2010. [S.I: s.n.], 2010.

CURRIE, C. et al. Inequalities in young people's health. HBSC international report from the 2005/2006 survey. Scotland: [s.n.], 2008.

ELICKER, E. et al. Use of alcohol, tobacco and other drugs by adolescent students from Porto Velho-RO, Brazil. Epidemiologia e Serviços de Saúde, Brasília, v. 24, n. 3, p. 399-410, set./2015. doi: 10.5123/S1679-49742015000300006.

GONCALVES, Jurema Ribeiro Luiz et al. Adesão ao tratamento: percepção de adolescentes dependentes químicos. SMAD, Rev. Eletrônica Saúde Mental Álcool Drog. (Ed. port.), Ribeirão Preto, v. 15, n. 1, p. 57-83, 2019. doi: 10.11606/issn.1806-6976.smad.2019.000415.

MALTA, D. C. et al. Prevalência do consumo de álcool e drogas entre adolescentes: Análise dos dados da Pesquisa Nacional de Saúde Escolar. Revista Brasileira de Epidemiologia, 2011. doi: 10.1590/S1415-790X2011000500014.

MARQUES, A. C. P. R.; CRUZ, M. S. O adolescente e o uso de drogas. Revista Brasileira de Psiquiatria, 2000. doi: 10.1590/s1516-44462000000600009.

MIOZZO, L. et al. Consumo de substâncias psicoativas em uma amostra de adolescentes e sua relação com o comportamento sexual. Jornal Brasileiro de Psiquiatria, 2013. doi: 10.1590/S0047-20852013000200001.

MORGADO, A. F.; IGUCHI, T.; BUENO, J. R. Epidemiologia da Dependência de Drogas em Grupos Populacionais do Brasil. [Epidemiology of drug dependence in Brazil.]. Jornal Brasileiro de Psiquiatria, 1983.

NASCIMENTO, C. R. R.; TRINDADE, Z. A. Criando meninos e meninas: Investigação com famílias de um bairro de classe popular. Arquivos Brasileiros de Psicologia, 2010. 
REIS, L. F. et al. Factors associated with early sexual initiation and unsafe sex in adolescents: Substance use and parenting style: subtítulo do artigo. Journal of Adolescence. Sao Paulo, v. 79, Número, p. 128-135, 2020. doi 10.1016/j.adolescence.2019.12.015.

RIZZINI, Irene; COUTO, R. M. B. D. População infantil e adolescente nas ruas: Principais temas de pesquisa no Brasil: subtítulo do artigo. Revista de Ciências Sociais, Rio de Janeiro, v. 19, n. 1, mar./2019. doi: 10.15448/1984-7289.2019.1.30867.

SALMANZADEH, H. et al. Adolescent Drug Exposure: A Review of Evidence for the Development of Persistent Changes in Brain Function. Brain Research Bulletin, Tehran, v. 156, p. 105-117, jan./2020. doi: 10.1016/j.brainresbull.2020.01.007.

SANTOS MODELLI, M. E. DOS; PRATESI, R.; TAUIL, P. L. [Blood alcohol concentration in fatal traffic accidents in the Federal District, Brazil]. Revista de saude publica, 2008. doi: $10.1590 /$ S0034 89102008005000012 .

SCHENKER, M.; MINAYO, M. C. DE S. A implicação da família no uso abusivo de drogas: uma revisão crítica. Ciência \& Saúde Coletiva, 2003. doi: 10.1590/S1413-81232003000100022.

SCHENKER, M.; MINAYO, M. C. DE S. Fatores de risco e de proteção para o uso de drogas na adolescência. Ciência \& Saúde Coletiva, 2005. doi: 10.1590/S1413-81232005000300027.

SIEGFRIED, N. et al. Restricting or banning of alcohol advertising to reduce alcohol consumption in adults and adolescents. Cochrane Database of Systematic Reviews, 2013. doi: 10.1002/14651858.CD010704.pub2.

SKOGEN, J. C. et al. Use of alcohol, tobacco and illicit drugs among ethnic Norwegian and ethnic minority adolescents in Hordaland county, Norway: the youth@hordaland-survey. Ethnicity and Health, 2018. doi: 10.1080/13557858.2016.1246422.

SOUZA, E. R. DE. Masculinidade e violência no Brasil: contribuições para a reflexão no campo da saúde. Ciência \& Saúde Coletiva, 2005. doi: 10.1590/S1413-81232005000100012.

STOCKWELL, T. et al. International Guide for Monitoring Alcohol Consumption and Harm. World Health Organization. [S.I: s.n.], 2000.

\section{Authorship contributions}

\section{1 - Mirene Peloso}

Universidade Federal de Viçosa, Viçosa, MG, Brasil. Professora pesquisadora, Mestre em Ciências da Saúde.

https://orcid.org/0000-0003-3272-60526 - mirene.peloso@gmail.com Contribuição: Data curation; Writing - original draft 


\section{2 - Brunnella Alcantara Chagas de Freitas}

Universidade Federal de Viçosa, Viçosa, MG, Brasil. Professora pesquisadora, Doutora em Ciência da Nutrição https://orcid.org/0000-0002-7863-0681 - brunnella.freitas@ufv.br Contribuição: Formal Analysis; Writing - review \& edition

\section{3 - Bruno David Henriques}

Universidade Federal de Viçosa, Viçosa, MG, Brasil. Professor pesquisador, Doutor em Ciências da Saúde. https://orcid.org/0000-0002-6844-6661 - bruno.david@ufv.br Contribuição: Writing - review \& edition

\section{4 - Samuel de Souza Magalhães Marques}

Universidade Federal de Viçosa, Viçosa, MG, Brasil. Acadêmico de Medicina e Bolsista de Iniciação Científica pelo CNPq em 2019 e 2020.

https://orcid.org/0000-0003-3707-484X - ssmagalhaesmarques@gmail.com Contribuição: Writing - original draft

\section{5 - Luciana Moreira Lima}

Vínculo institucional, titulação: Universidade Federal de Viçosa, Viçosa, MG, Brasil. Professora pesquisadora, Doutora em Ciências Farmacêuticas. https://orcid.org/0000-0001-5349-1577 - luciana.lima@ufv.br Contribuição: Supervision; Writing - review \& edition 